\title{
Reporting immunization coverage inequalities in Pakistan
}

Nicole Bergen, ${ }^{1}$ Grace Zhu ${ }^{1}$ and Katherine Kirkby ${ }^{2}$

${ }^{1}$ University of Ottawa, Ottawa, Canada. (Correspondence to: N. Bergen: nicolejbergen@gmail.com). ${ }^{2}$ World Health Organization Headquarters, Geneva, Switzerland.

\begin{abstract}
Background: Immunization coverage in Pakistan is unequally distributed. Understanding the current status of reporting of immunization coverage inequalities in Pakistan can help to identify gaps and opportunities for strengthened monitoring and reporting.
\end{abstract}

Aims: To assess the published literature on immunization coverage inequality measurement and reporting in Pakistan.

Methods: We performed a literature search in PubMed in April 2019 to obtain articles reporting inequalities in immunization coverage in Pakistan. A data extraction rubric was applied to collate information about data sources, immunization indicators and dimensions of inequality.

Results: We included 42 studies in our analysis. Most studies reported data from household surveys or research studies. Dimensions of inequality reflected geography (primarily provinces/territories), economic status, place of residence, education level, sex and occupation. District-level comparisons were featured in 5 studies that were subnational in scope.

Conclusions: Expanded monitoring at district level is warranted as a major way forward in characterizing immunization inequalities in Pakistan.

Keywords: Pakistan, inequality, immunization coverage

Citation: Bergen N; Zhu G; Kirkby K. Reporting immunization coverage inequalities in Pakistan. East Mediterr Health J. 2021;27(1):83-89. https://doi. org/10.26719/emhj.20.081

Received: 16/10/19; accepted: 20/01/20

Copyright (c) World Health Organization (WHO) 2021. Open Access. Some rights reserved. This work is available under the CC BY-NC-SA 3.0 IGO license (https://creativecommons.org/licenses/by-nc-sa/3.o/igo).

\section{Introduction}

Despite recent national improvements to immunization coverage in Pakistan (1), the country has not yet realized the full benefits of immunization. The reasons why Pakistan trails behind in terms of immunization can be traced to political, geographical and sociocultural forces, which are experienced differently throughout the country $(2,3)$. As a result, Pakistan has high levels of immunization coverage inequality, with marked differences according to parental education, household economic status, subnational region and other factors $(4,5)$.

Health inequality monitoring methods can be used to measure and track immunization coverage differences between subgroups within a target population $(6,7)$. Inequality monitoring can help to identify where immunization coverage inequalities exist, and the characteristics of disadvantaged subgroups. Among other factors, the inequality monitoring process is premised on data availability and the identification of population subgroups that reflect relevant (and actionable) dimensions of inequality.

A comprehensive overview of how inequality monitoring efforts have assessed immunization coverage in Pakistan is warranted to characterize the current scope of monitoring, reveal gaps in monitoring, and indicate opportunities to strengthen and expand monitoring. Here, we report the results of a systematic survey of published literature about immunization coverage inequality in Pakistan between 2000 and 2019, with a focus on data sources and dimensions of inequality. The authors alone are responsible for the views expressed in this article and they do not necessarily represent the views, decisions or policies of the institutions with which they are affiliated.

\section{Methods}

Two of the authors performed a systematic literature on PubMed (Medline) in April 2019. The search strategy used Boolean operators, Medical Subject Headings terms and title/abstract keywords to search for articles on Pakistan and immunization. Filters were applied to refine the search criteria according to language (English) and date (after 2000) of publication. The search results were screened in 2 stages: first by title and abstract, and then by full text. The following inclusion criteria were applied: (1) full text of article available online; (2) article pertained to humans; (3) article reported immunization coverage for Pakistan; (4) article contained disaggregated data for immunization coverage in Pakistan; (5) article stated the data source; and (6) article reported monitoring of immunization coverage according to demographic, sociocultural or geographic factors, or other perceived sources of systemic discrimination. Articles that evaluated the impact of an intervention or trial were not included. A data extraction rubric was used to extract key information from articles included at the full-text review stage. The rubric collected standardized and freeform information, including: publication details, target population, data sources, immunization indicators, disaggregation criteria and 
population subgroups. Both authors contributed to article screening and data extraction, and incongruities were resolved through discussion and consensus. Detailed information about the search strategy and data extraction rubric is available from the authors upon request.

\section{Results}

\section{Characteristics of included articles}

The literature search yielded 42 relevant articles (Table 1). The included articles were published in international ( $n=$ $28)$, regional $(n=6)$ or national $(n=8)$ journals, and predominantly reported on the national population $(n=24)$ or geographically determined subnational populations ( $n$ $=15$ ). The majority of articles were original research studies $(n=31)$, followed by reports $(n=8)$ and reviews $(n=3)$. A complete list of included articles is available in Appendix 1. The articles reported coverage of single vaccines, including polio $(n=17)$, diphtheria, tetanus, and pertussis $(n=7)$, measles $(n=7)$ and hepatitis $B(n=5)$, or coverage of multiple vaccines $(n=13)$.

\section{Data sources}

The data used to measure inequalities in immunization coverage were sourced from international or national household surveys $(n=16)$ or collected as part of a research study $(n=16)$, with 10 additional articles reporting World Health Organization/United Nations Children's Fund (WHO/UNICEF) modelled estimates based on official country estimates. Household survey sources included 2 prominent international surveys: the Pakistan Demographic and Health Survey (PDHS) $(n=11)$ and the Multiple Indicator Cluster Surveys (MICS) $(n=1)$. While articles using PDHS data were national in scope, the PDHS excludes certain geographical areas [e.g. the 2012-2013 PDHS did not include Azad Jammu and Kashmir (Pakistan-administered Kashmir) and Federally Administered Tribal Areas]. Since 2010, MICS has been conducted on a rotating basis by province/territory. The article using MICS data reported on subnational populations in Balochistan and Punjab. Other household surveys included the Pakistan Social and Living Standards Measurement $(n=4)$, Pakistan Integrated Household Survey (or Pakistan Integrated Economic Survey) $(n=3)$, Expanded Programme on Immunization surveys $(n=2)$, National Nutrition Survey $(n=1)$ and Maternal and Child Health Program Indicator Survey $(n=1)$. Articles that reported data collected as part of a research study $(n=16)$ all represented populations within specific provinces or territories: Sindh $(n=7)$, Khyber Pakhtunkhwa $(n=6)$, Balochistan $(n=1)$, Azad Jammu and Kashmir $(n=1)$ and multiple provinces (Sindh, Khyber Pakhtunkhwa and Punjab) $(n=1)$.

\section{Dimensions of inequality}

Over half of the articles disaggregated immunization coverage by subnational region $(n=25)$. Other major dimensions of inequality included: economic status ( $n$ $=18)$, rural-urban place of residence $(n=18)$, education level $(n=16)$, sex $(n=15)$ and occupation $(n=9)$. Of the 25 articles that reported subnational region as a dimension of inequality, data were most often disaggregated by provinces and territories $(n=20)$. These articles drew from WHO/UNICEF estimates $(n=10)$, PDHS $(n=5)$ or national household surveys $(n=5)$, and were national in scope. Five articles, subnational in scope, reported district or subdistrict inequalities in coverage (Table 2).

\section{Discussion}

This literature review demonstrates the scope of immunization inequality reporting in Pakistan. Although many studies were national in scope, some geographical regions were not covered by major household surveys and thus not reported in the studies. It is a concern that conflict-affected and unstable areas are not included in regular data collection, as they are also areas where vac-

\begin{tabular}{|c|c|c|}
\hline Stage of search/review & Reason for exclusion (no. of articles) & No. of articles \\
\hline Titles identified through database searching & & 1231 \\
\hline Applied filter: articles published since 2000 & Articles published outside of specified timeframe $(n=184)$ & 1047 \\
\hline Duplicates removed & $(n=192)$ & 855 \\
\hline Applied filter: articles published in English & $\begin{array}{l}\text { Articles published in Spanish }(n=5) \text {, Danish }(n=2) \text {, French }(n=2) \text {, } \\
\text { Japanese }(n=2) \text {, Dutch }(n=1) \text {, German }(n=1) \text {, Serbian }(n=1) \text { or Swedish } \\
(n=1)\end{array}$ & 840 \\
\hline $\begin{array}{l}\text { Removed items catalogued as "Species: other } \\
\text { animals" for content unrelated to humans }\end{array}$ & Article did not contain information about human subjects ${ }^{a}(n=103)$ & 734 \\
\hline Title and abstract review & $\begin{array}{l}\text { Articles did not contain information about human subjects; did } \\
\text { not report immunization coverage for Pakistan; did not contain } \\
\text { disaggregated data for Pakistan; did not disaggregate data by relevant } \\
\text { demographic, socioeconomic, cultural, or geographic factors }(n=650)\end{array}$ & 87 \\
\hline Full-text review & $\begin{array}{l}\text { Article did not report immunization coverage for Pakistan }(n=40) \\
\text { Article did not disaggregate data by relevant demographic, } \\
\text { socioeconomic, cultural, or geographic factors }(n=3) \\
\text { Full text of article was not available }(n=2)\end{array}$ & 42 \\
\hline
\end{tabular}

${ }^{a}$ These titles were reviewed for potentially relevant articles, and one article was retained. 


\begin{tabular}{|c|c|c|c|c|}
\hline First author (ref) & Title of article & Data source & Study location & Subnational regions \\
\hline Cockcroft (14) & $\begin{array}{l}\text { One size does not fit all: local } \\
\text { determinants of measles } \\
\text { vaccination in } 4 \text { districts of } \\
\text { Pakistan }\end{array}$ & Research study & $\begin{array}{l}\text { Sindh, Punjab and } \\
\text { North West Frontier } \\
\text { province }^{\text {a }}\end{array}$ & $\begin{array}{l}\text { Select districts: Khairpur, } \\
\text { Haripur, Khanewal, Sialkot }\end{array}$ \\
\hline Imran (11) & $\begin{array}{l}\text { Routine immunization in } \\
\text { Pakistan: comparison of } \\
\text { multiple data sources and } \\
\text { identification of factors } \\
\text { associated with vaccination }\end{array}$ & MICS & $\begin{array}{l}\text { Balochistan and } \\
\text { Punjab }\end{array}$ & $\begin{array}{l}\text { District groups within } \\
\text { Balochistan and districts within } \\
\text { Punjab }\end{array}$ \\
\hline Khowaja (18) & $\begin{array}{l}\text { Routine EPI coverage: } \\
\text { subdistrict inequalities and } \\
\text { reasons for immunization } \\
\text { failure in a rural setting in } \\
\text { Pakistan }\end{array}$ & Research study & Matiari district, Sindh & $\begin{array}{l}\text { Matiari district talukas and } \\
\text { union councils }\end{array}$ \\
\hline $\operatorname{Riaz}(19)$ & $\begin{array}{l}\text { Reasons for nonvaccination } \\
\text { and incomplete vaccinations } \\
\text { among children in Pakistan }\end{array}$ & Research study & Sindh & $\begin{array}{l}\text { Select districts: Karachi, } \\
\text { Hyderabad, Matriari, Jamshoro, } \\
\text { Thatta, Sujawal, Tando } \\
\text { Muhammad Khan, Tando Allah } \\
\text { Yar }\end{array}$ \\
\hline Siddiqi (20) & $\begin{array}{l}\text { Ethnic disparities in routine } \\
\text { immunization coverage: } \\
\text { a reason for persistent } \\
\text { poliovirus circulation in } \\
\text { Karachi, Pakistan? }\end{array}$ & Research study & Periurban Karachi & $\begin{array}{l}\text { Communities: Baldia, BinQasim, } \\
\text { Gadap, Gulberg, Gulshan, } \\
\text { Jamshed, Kemari, Korangi, } \\
\text { Landhi, Liaqatabad, Lyari, Malir, } \\
\text { New Karachi, North Nazimabad, } \\
\text { Orangi, Saddar, Shah Faisal, SITE }\end{array}$ \\
\hline
\end{tabular}

${ }^{a}$ now known as Khyber Pakhtunkhwa.

EPI = Expanded Programme on Immunization; MICS = Multiple Indicator Cluster Surveys.

cine-preventable diseases are likely to be more prevalent or problematic. The transmission of wild poliovirus, for instance, originates from regions, including Federally Administered Tribal Areas, where surveillance systems are suboptimal and immunization activities, routinely compromised (8).

The results indicate a reliance on household survey and research data, with low use of data from administrative sources (records from routine encounters with the health system, which are taken into account in the WHO/UNICEF modelled estimates). Administrative data have important potential for inequality monitoring, as they can provide timely information gathered from all members of a population, with high geographical precision. The quality of administrative data, however, relies on accurate and coordinated reporting systems as well as denominator estimates (typically generated through censuses) (9). Unfortunately, Pakistan's health information system lacks capacity (10), and therefore immunization coverage estimates derived from this system tend to be discrepant from survey-derived estimates (11).

Given the decentralization of the health system in Pakistan since 2011 - which devolved national responsibilities to provincial and district-level officials, raising equity concerns $(10,12)$ - and the practical importance of area-based inequality monitoring (13), geographical monitoring is particularly important to close coverage gaps. To date, published inequality analyses conducted at the district or subdistrict level are small in number, and appear to be primarily undertaken for specific research purposes rather than as part of routine inequality monitoring. Notably, however, coverage estimates within districts of the same province were variable, and thus provincial data did not necessarily reflect the situation within a particular district (14). No study included in this analysis reported district-level inequalities across the entire country.

A wider survey of publicly available grey literature (i.e., published online by the Government of Pakistan Ministry of National Health Services, Regulation and Coordination, and organizations involved in promoting immunization) presented some district-level disaggregation of immunization coverage, although detailed background documents about these analyses were not readily available $(15,16)$. Consultations with national and international immunization experts have revealed that immunization data at a district level (aligning with national administrative units) were preferred by country-level immunization experts, and that small-area estimations were ranked as a top research priority (17). Participants in that consultation, however, also noted the costly nature of collecting data with district-level granularity, and cited quality and logistical complexities.

Overall, the results of this preliminary analysis suggest an international and national interest in monitoring immunization inequalities in Pakistan, with a predominant focus on geographically defined inequalities (noting that other dimensions are also 
monitored). Expanded monitoring at district level is a major way forward in characterizing immunization inequalities and targeted responses, and should be pursued on a national scale, especially including geographical areas that are less well represented in prominent data sources. Additionally, further studies are warranted to expand upon the methods used in this preliminary analysis, including multiple databases and handsearching of relevant unindexed journals. The results of this analysis draw attention to the continued need for regular inequality monitoring of immunization coverage as a central part of national efforts to ensure the full benefits of immunization for all.

\section{Funding: None.}

Competing interests: None declared.

\section{Rapport sur les inégalités en matière de couverture vaccinale au Pakistan Résumé}

Contexte : La couverture vaccinale au Pakistan est inégale. Comprendre la situation actuelle concernant la notification des inégalités en matière de couverture vaccinale au Pakistan peut aider à identifier les lacunes et les possibilités de renforcement du suivi et de la notification.

Objectifs : Évaluer la littérature publiée sur la mesure et la notification concernant les inégalités liées à la couverture vaccinale au Pakistan.

Méthodes: Nous avons réalisé une recherche de littérature dans PubMed en avril 2019 pour obtenir des articles signalant des inégalités dans la couverture vaccinale au Pakistan. Une grille d'extraction des données a été utilisée pour recueillir des informations sur les sources de données, les indicateurs de vaccination et les dimensions des inégalités.

Résultats: Nous avons inclus 42 études dans notre analyse. La plupart des études ont fourni des données issues d'enquêtes auprès des ménages ou d'études de recherche. Les dimensions de l'inégalité reflètent la géographie (principalement les provinces/territoires), le statut économique, le lieu de résidence, le niveau d'études, le sexe et la profession. Des comparaisons au niveau des districts ont été présentées dans cinq études de portée infranationale.

Conclusions : Un suivi étendu au niveau des districts est nécessaire pour permettre une meilleure caractérisation des inégalités en matière de vaccination au Pakistan.

$$
\begin{aligned}
& \text { التبليغ بأوجه التفاوت في التغطية بالتحصين في باكستان } \\
& \text { نيكول بيرجن، جريس زو، كاثرين كيركبي } \\
& \text { الخلاصة }
\end{aligned}
$$

الخلفية: يتسم توزيع التغطية بالتحصين في باكستان بعدم التكافؤ. ويمكن أن يساعد فهم الوضع الحالي للتبليخ بأوجه عدم التكافؤ في التغطية

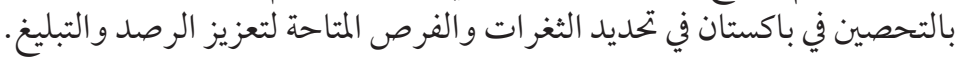
الأهداف: هدفت هذه الدراسة إلى تقييم الأدبيات المنشورة حول قياس التفاوت في التغطية بالتحصين و التبليخ به في باكستان. طرق البحث: أجرينا استعراضاً للمؤلفات باستخدام برنامج PubMed في أبريل/ نيسان 2019 للحصول على مقالات أبلغت بعدم التكافؤ في

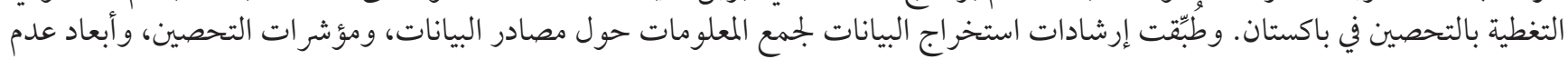
التكافؤ.

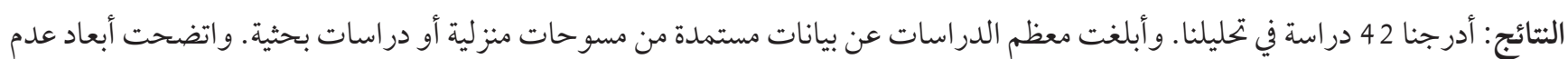

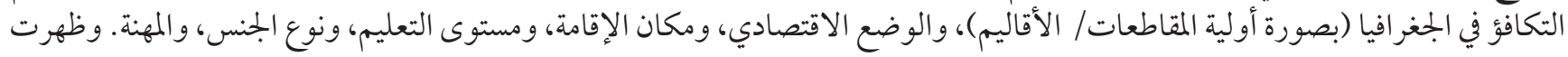
مقارنات على مستوى المناطق في 5 دراسات تمت على على نطاق دون إطعات وطني.

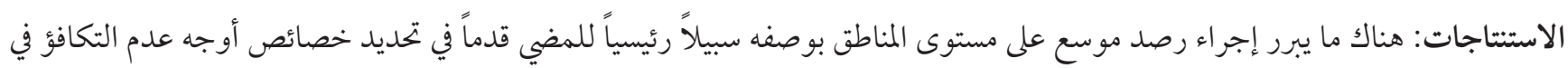
التحصين في باكستان. 


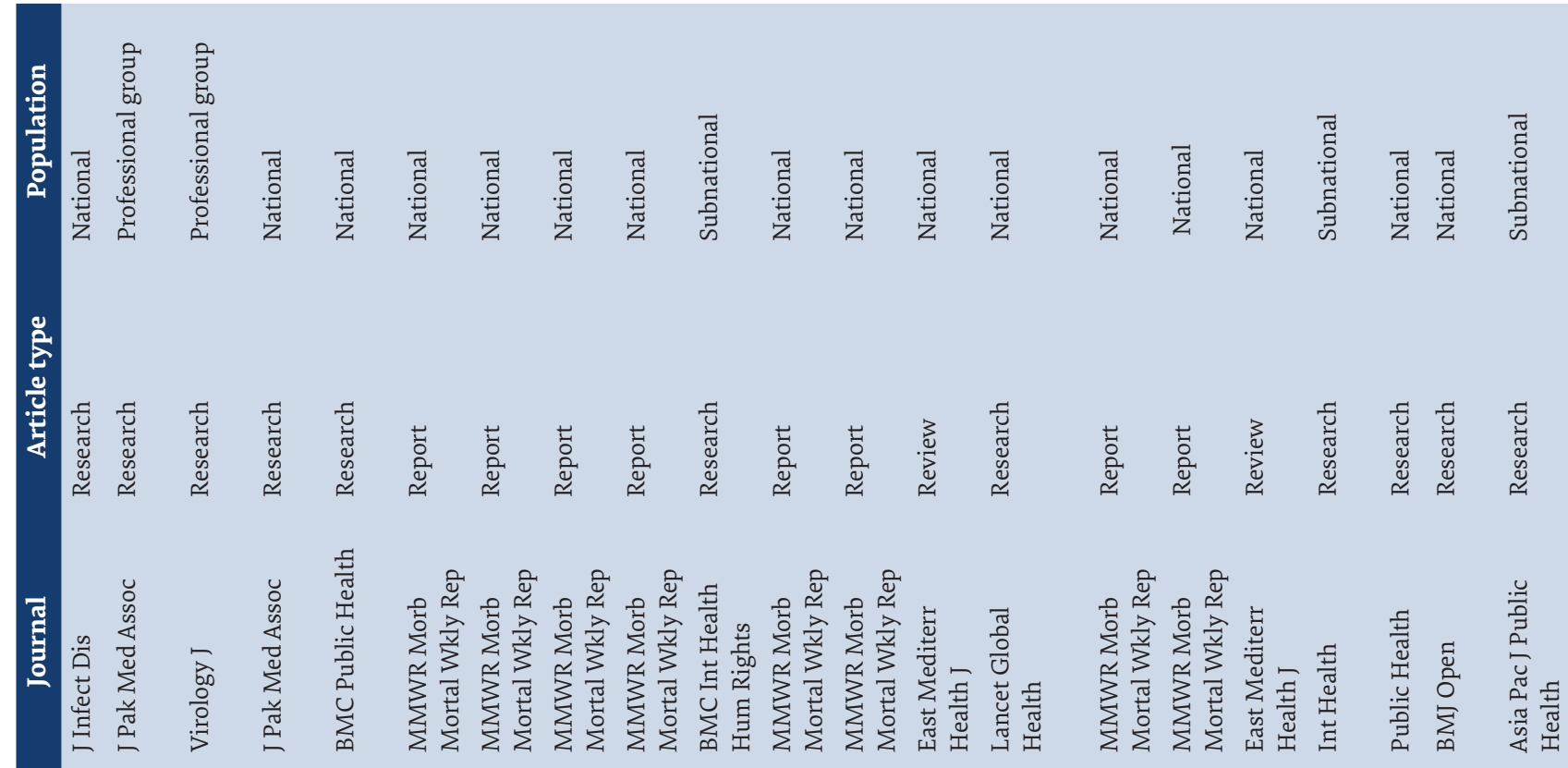



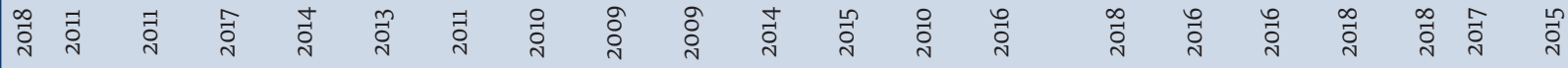

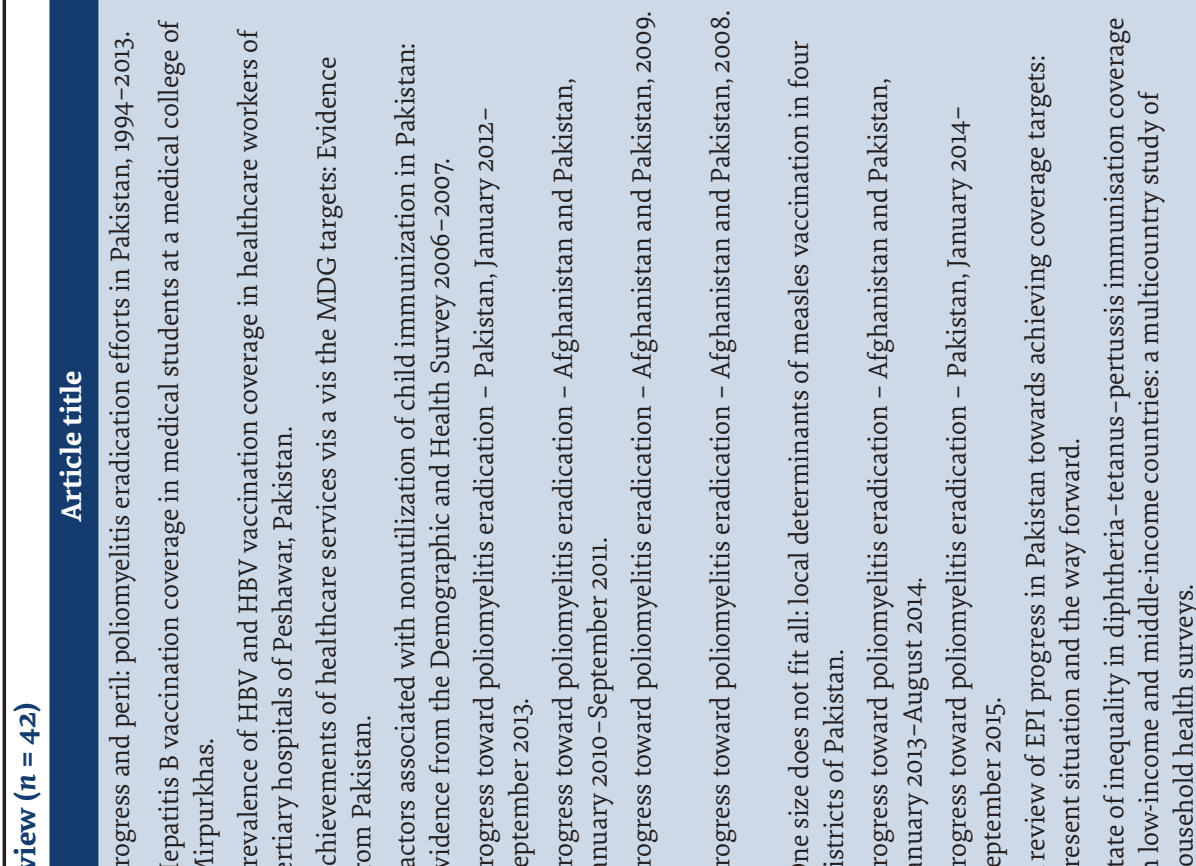

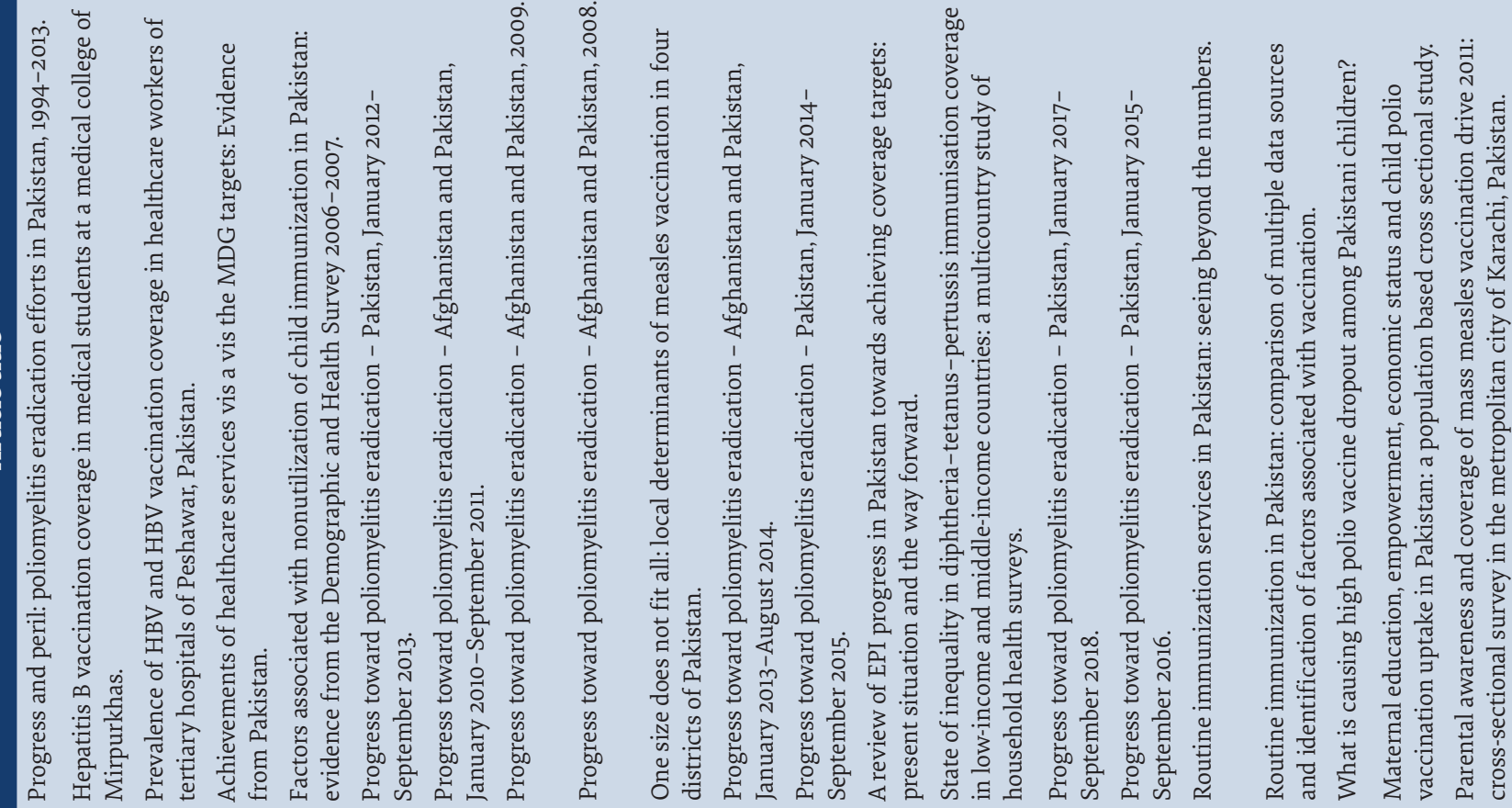

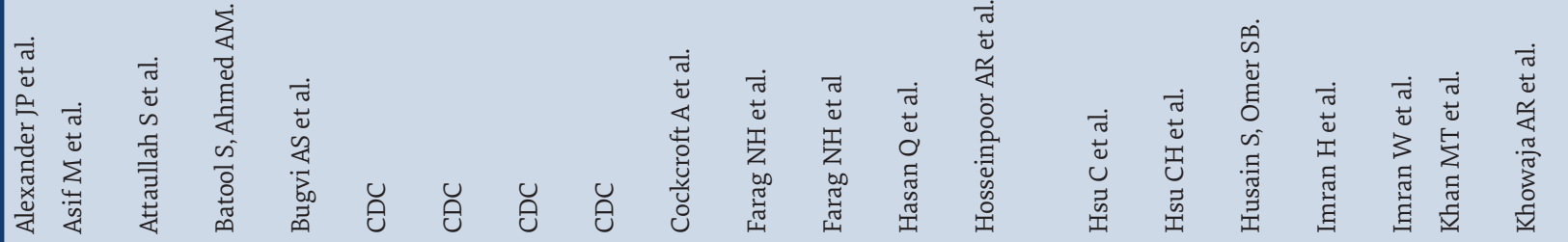




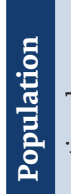

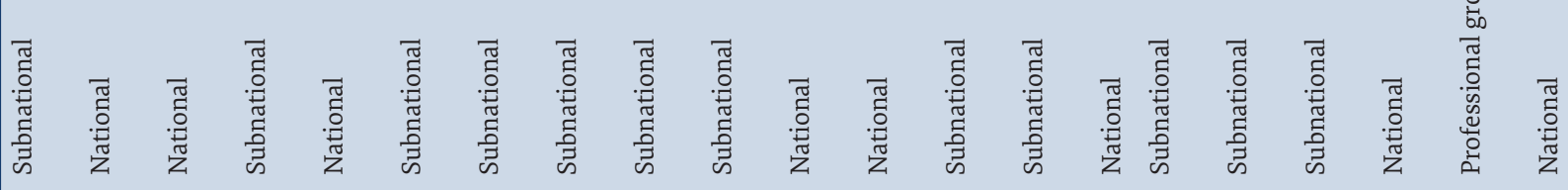

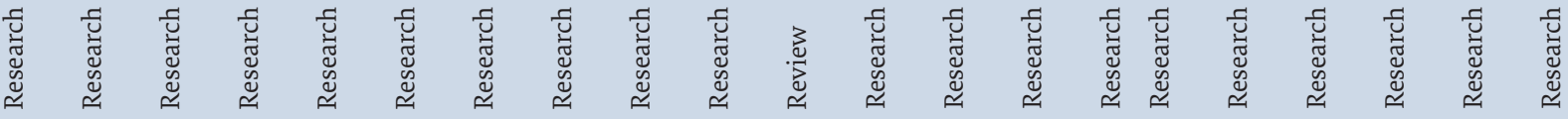

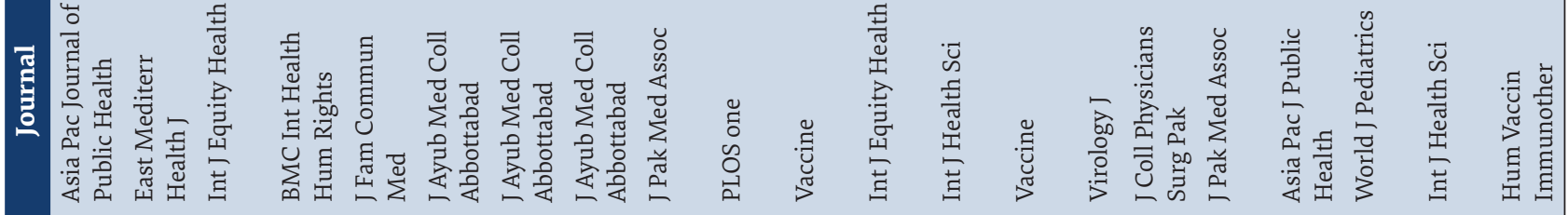

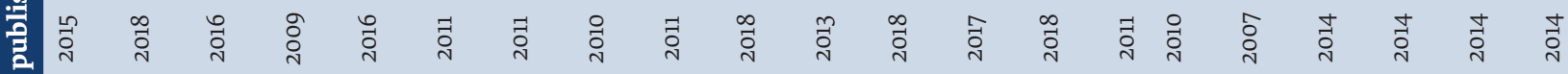




\section{References}

1. WHO vaccine-preventable diseases: monitoring system. 2019 global summary [website]. Geneva: World Health Organization; 2019 (https://apps.who.int/immunization_monitoring/globalsummary/estimates?c=PAK, accessed 16 June 2020).

2. Bhutta ZA, Hafeez A, Rizvi A, Ali N, Khan A, Ahmad F, et al. Reproductive, maternal, newborn, and child health in Pakistan: challenges and opportunities. The Lancet. 2013 Jun 222;381(9884):2207-18. http://dx.doi.org/10.1016/So140-6736(12)61999-0 PMID:23684261

3. Owais A, Khowaja AR, Ali SA, Zaidi AKM. Pakistan's expanded programme on immunization: an overview in the context of polio eradication and strategies for improving coverage. Vaccine. 2013 Jul 18;31(33):3313-9. https://doi.org/10.1016/j.vaccine.2013.05.015

4. State of inequality: childhood immunization. Geneva: World Health Organization; 2016 (https://www.who.int/gho/health_equity/ report_2016_immunization/en/, accessed 16 June 2020).

5. Explorations of inequality: childhood immunization. Geneva: World Health Organization; 2018 (https://www.who.int/gho/ health_equity/report_2018_immunization/en/, accessed 16 June 2020).

6. Inequality monitoring in immunization: a step-by-step manual. Geneva: World Health Organization; 2019 (https://www.who.int/ gho/health_equity/manual_immunization/en/, accessed 16 June 2020).

7. Handbook on health inequality monitoring: with a special focus on low- and middle-income countries. Geneva: World Health Organization; 2013 (https://www.who.int/gho/health_equity/handbook/en/, accessed 16 June 2020).

8. Hussain SF, Boyle P, Patel P, Sullivan R. Eradicating polio in Pakistan: an analysis of the challenges and solutions to this security and health issue. Glob Health. 2016 Oct 12;12(1):63. http://dx.doi.org/10.1186/s12992-016-0195-3 PMID:27729081

9. Victora CG, Ryman TK. Potential approaches to better measure and track equity in immunization using survey and administrative data, and data triangulation. ERG Discussion Paper 02. Equity Reference Group for Immunization; 2018 (https://drive.google. com/file/d/1z6t9P_Av9J1yEpJmATPhTS_P5jiGTmIE/view, accessed 16 June 2020).

10. Nishtar S, Boerma T, Amjad S, Alam AY, Khalid F, ul Haq I, et al. Pakistan's health system: performance and prospects after the 18th Constitutional Amendment. The Lancet. 2013 Jun 22;381(9884):2193-206. http://dx.doi.org/10.1016/So140-6736(13)60019-7 PMID:23684254

11. Imran H, Raja D, Grassly NC, Wadood MZ, Safdar RM, O’Reilly KM. Routine immunization in Pakistan: comparison of multiple data sources and identification of factors associated with vaccination. Int Health. 2018 Mar 1;10(2):84-91. http://dx.doi. org/10.1093/inthealth/ihx067 PMID:29432552

12. Bossert TJ, Mitchell AD, Janjua MA. Improving health system performance in a decentralized health system: capacity building in Pakistan. Health Syst Reform. 2015 May 19;1(4):276-84. http://dx.doi.org/10.1080/23288604.2015.1056330 PMID:31519095

13. Hosseinpoor AR, Bergen N. Area-based units of analysis for strengthening health inequality monitoring. Bull World Health Organ. 2016 Nov 1;94(11):856-8. http://dx.doi.org/10.2471/BLT.15.165266 PMID:27821889

14. Cockcroft A, Andersson N, Omer K, Ansari NM, Khan A, Chaudhry UU, et al. One size does not fit all: local determinants of measles vaccination in four districts of Pakistan. BMC Int Health Hum Rights. 2009 Oct 14;9(Suppl 1):S4. http://dx.doi. org/10.1186/1472-698X-9-S1-S4 PMID:19828062

15. Annual progress report 2014. Submitted by the Government of Pakistan. Geneva: Gavi; 2014 (https://www.gavi.org/country/pakistan/documents/aprs/annual-progress-report-pakistan-2014/, accessed 16 June 2020).

16. Hafeez A. Case study: improving sustainable immunisation coverage in Pakistan in partnership with the Alliance; Geneva: Gavi; 2017 (https://www.gavi.org/about/governance/gavi-board/minutes/2017/14-june/presentations/o7b---improving-sustainable-immunisation-coverage-in-pakistan-in-partnership-with-the-alliance/, accessed 16 June 2020).

17. Danovaro-Holliday MC, Dansereau E, Rhoda DA, Brown DW, Cutts FT, Gacic-Dobo M. Collecting and using reliable vaccination coverage survey estimates: summary and recommendations from the "Meeting to share lessons learnt from the roll-out of the updated WHO Vaccination Coverage Cluster Survey Reference Manual and to set an operational research agenda around vaccination coverage surveys", Geneva, 18-21 April 2017. Vaccine. 2018 Aug 16;36(34):5150-9. http://dx.doi.org/10.1016/j.vaccine.2018.07.019 PMID:30041880

18. Khowaja AR, Zaman U, Feroze A, Rizvi A, Zaidi AK. Routine EPI coverage: subdistrict inequalities and reasons for immunization failure in a rural setting in Pakistan. Asia Pac J Public Health. 2015 Mar;27(2):NP1050-9. http://dx.doi. org/10.1177/1010539511430850 PMID:22186395

19. Riaz A, Husain S, Yousafzai MT, Nisar I, Shaheen F, Mahesar W, et al. Reasons for non-vaccination and incomplete vaccinations among children in Pakistan. Vaccine. 2018 Aug 23;36(35):5288-93. http://dx.doi.org/10.1016/j.vaccine.2018.07.024 PMID:30054162

20. Siddiqi NT, Owais A, Agha A, Karim MS, Zaidi AKM. Ethnic disparities in routine immunization coverage: a reason for persistent poliovirus circulation in Karachi, Pakistan? Asia Pac J Public Health. 2014 Jan;26(1):67-76. http://dx.doi. org/10.1177/1010539513475648 PMID:23420055 